\section{Omfattende, men litt rotete om anestesi ved fedme}

Ortiz VE, Wiener-Kronish J, red.

Perioperative anesthetic care of the obese patient

223 s, tab, ill. London: Informa Healthcare,

2009. Pris GBP 150

ISBN 978-1-4200-9530-2

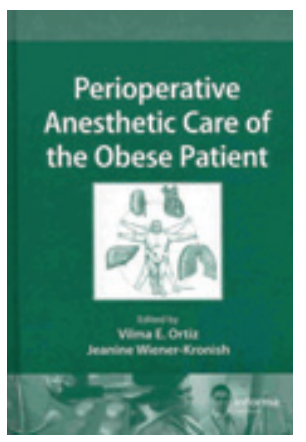

Fedme og ekstrem fedme forefinnes med økende hyppighet hos operasjonspasienter, både ved blandet kirurgi og (selvfølgelig!) ved fedmereduksjonskirurgi, som er blitt et vanlig inngrep ved en del sentre. Med denne utgi-

velsen ønsker man primært å henvende seg til praktiserende anestesiologer og formidle oppdatert kunnskap om organfysiologi ved fedme, preoperativ evaluering og planlegging, anestesiologisk gjennomføring under operasjon samt postoperativ oppfølging.

Perioperative anesthetic care of the obese patient er tettskrevet, men greit inndelt med overskrifter og punkter og en god stikkordliste, i solid innbundet A5-format, med sparsomt innslag av tabeller og en knapp håndfull svart-hvitt-bilder. Den er redigert av to anestesiologer fra det tunge fagmiljøet ved Massachusetts General Hospital, én med klinisk erfaring fra fagfeltet og én med generell forskningserfaring. De 20 kapitlene er skrevet av 25 inviterte forfattere, den ene redaktøren er medforfatter av to.

Det er mye god informasjon, spesielt i første del om organfysiologi og fedmefysiologi. Det er rikelig med referanser til litteratur som diskuteres, men det tas i for liten grad standpunkt til hva man faktisk anbefaler å gjøre når litteraturen noen ganger er motstridende og vag. Mangel på stram redigering av fagstoffet fra de mange forfatterne er viktigste svakhet. En rekke temaer, f.eks. søvnapné, trombosetendens og blodtrykksmålinger, omtales overlappende flere steder uten at det gis klare konklusjoner. Kapitlene som er knyttet til praktisk viktige felter som medikamentfarmakologi og -dosering er noe overfladiske, beheftet med småfeil og igjen vanskelig å trekke konkrete råd fra. Det samme gjelder kapitlene som er knyttet til postoperativ håndtering, spesielt smertebehandling. Innimellom er det en del viktige praktiske tips, mens f.eks. faremomentene ved å anbefale trykkontrollert ventilasjon ved svingende laparoskopi trykk i buken ikke omtales.

Tre gode kapitler om henholdsvis obstetrikk, barn og traumehåndtering hos fedmepasienter trekker inntrykket opp. Det siste har en mye mer konkret oppbygning, med råd og konklusjoner, enn teksten for øvrig.

Styrken er svært omfattende referanselister og til dels grei gjennomgang av tilgjengelig forskningslitteratur. Det gis i liten grad kokebokliknende oppskrifter og konklusjoner, men en erfaren anestesiolog vil finne mange nyttige råd og tips innimellom. Første del vil også være nyttig lesning for andre grupper som behandler fedmepasienter. Perioperative anesthetic care of the obese patient kan anbefales som oppslagsbok ved anestesiavdelinger og for andre som behandler fete pasienter samt til gjennomlesing og fordypning hos kolleger som selv kan sortere ut råd og praktiske rutiner fra innholdet.

Johan Ræder

Anestesiavdelingen

Oslo Universitetssykehus, Ullevål

\section{Nyttig om anestesifagets anestesisøyle}

Ræder J.

\section{Anestesiologi}

En innføringsbok. 196 s, tab, ill. Oslo: Gyldendal Akademisk, 2009. Pris NOK 395

ISBN 978-82-05-39497-1

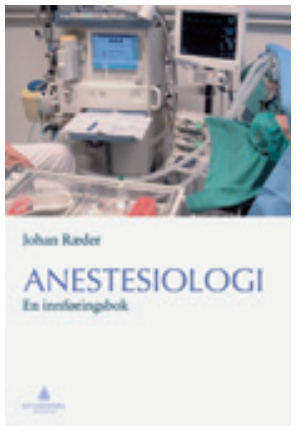

Målgruppen er i hovedsak medisinstudenter. Anestesiologi består av fem deler - det er fire deler etter anestesifagets fire søyler (anestesi, intensivmedisin, akuttmedisin og smertebehandling) samt en femte del som omhandler etikk. I tillegg finnes det en innledning, en vedleggsdel, en side om forfatteren og en nyttig stikkordliste. Innledningen og nesten hele vedleggsdelen hører til anestesidelen.

Anestesidelen dominerer altså - sammen med innledningen utgjør den nesten et dobbelt så stort volum som de tre andre søylene til sammen. Den inneholder sju kapitler (åtte inklusive innledningen), de andre søylene er kun representert med ett kapittel hver. I anestesidelen kompletteres teksten med bilder, tabeller og faktarammer for å sikre kunnskapsoverføringen, i tillegg til pasienteksempler som aktualiserer innholdet. Disse pedagogiske finessere eksisterer kun i denne delen. De andre består bare av tekst og et fåtall bilder.

Intensivdelen er summarisk og for kort $\mathrm{i}$ henhold til intensivmedisinens kliniske, økonomiske og etiske tyngde i sykehusene og dens multidisiplinære karakter. Teksten i denne delen er et par steder mindre klar og kan skape forvirring. Eksempel på dette er tittelen Septisk sjokk eller SIRS. «Septisk sjokk eller SIRS-sjokk» hadde vært å foretrekke. Akuttdelen og smertedelen er også meget kortfattet, noe som rammer både den minimale mengde kunnskap som bør formidles og kvaliteten i kunnskapsoverføringen. Etikkdelen, som er ekstra kort (5 s.), gir en oversikt over etiske problemstillinger $i$ de fire søylene og omhandler i virkeligheten mer helserett enn etikk. Etikk er av størst betydning i anestesifagets daglige liv, og det er gledelig at det $i$ det minste er funnet plass til en etikkdel i denne utgivelsen.

Det er få referanser - totalt 37 . Studenter er ikke interessert i tunge referanser som Miller's Anaesthesia uten en balansert liste over bøker, artikler og de nyttigste nettsidene. Flere internasjonale og studentvennlige referanser hadde sikkert økt den pedagogiske tyngden.

Språket er klart, med for det meste korte og middelslange setninger. Mindre klar er frasen «livløs pasient» i stedet for «pasient uten respirasjon og sirkulasjon». Uklarhet skapes også av ordet «anestesør», som brukes som samlenavn på anestesileger og anestesisykepleiere, noe som toner ned identitetsskillet mellom leger og ikke-leger Ifølge den norske presidenten i Scandinavian Society of Anaesthesiology and Intensive Care (SSAI) i nr. 2/2009 av Tidskrift for norsk anestesiologisk forening er anestesør (eng. «anaesthetist») en ikke-lege som er trent $\mathrm{i}$ å gi anestesi. Selv i denne 